\title{
Public Entities as Undertakings under Competition Rules
}

\section{MARTINA REPAS}

\begin{abstract}
This paper deals with undertakings, i.e., entities that are obliged to act in accordance with competition rules. This issue is one of the key elements for the application of competition rules. Its importance derives from severe consequences in case of breach of these rules that may give rise to fines, nullity of agreements, and in some regulations, even to criminal offences. For this purpose, the paper explains the notion of 'undertaking' as understood in the EU and Slovenian competition law systems. It deals especially with public bodies such as states, local communities, public institutes, and others that can also qualify as undertakings when they perform activities for pay in the market, and are thus obliged to follow competition rules. A review of the case law shows that many public entities have been under the Competition Authority's investigation of infringements of competition rules.
\end{abstract}

KEYwORDS: • competition law $\bullet$ public authority $\bullet$ undertaking • economic activity $\bullet$ association of undertakings $\bullet$ single economic entity $\bullet$ EU • Slovenia

Correspondence Address: Martina Repas, Ph.D., Assistant Professor, Faculty of Law, University of Maribor, Mladinska ulica 9, 2000 Maribor, Slovenia, email: martina.repas@uni-mb.si. 
The infringement of competition rules, as regulated by EU law, which consists of Treaty on the Functioning of the European Union (TFEU), ${ }^{1}$ several Council and Commission Regulations and Commission Notices, and Guidelines, causes serious consequences. The fine for restricting competition by agreement, for abuse of a dominant position, for failure to notify concentrations between undertakings, and for other conduct contrary to EU competition rules, defined by Council Regulation No 1/2003 of 16 December 2002 on the implementation of the rules on competition laid down in Articles 81 and 82 of the Treaty ${ }^{2}$ (Regulation 1/2003), and by Council Regulation No 139/2004 of 20 January 2004 on the control of concentrations between undertakings ${ }^{3}$ (Regulation 139/2004), may amount up to $10 \%$ of the total turnover of an undertaking in the preceding business year. ${ }^{4}$ In 2008, the Republic of Slovenia adopted the same method of sanctions for the breach of competition rules, and ensured the enactment of the new Prevention of the Restriction of Competition $\mathrm{Act}^{5}$ (SCA). The legislative intent was to bring the Slovenian regulation more into line with the EU regulation, and to introduce fines that are more individualised and efficient. There is no doubt that a fine determined according to the annual turnover of the undertaking in breach can represent a considerable amount for large-sized companies with high turnover, compared to the previous SCA regulations (1999) ${ }^{6}$. where fines were low and thus efficient only for small-sized companies and entrepreneurs. ${ }^{7}$ Besides fines, there are also other sanctions provided for breach of competition rules, including nullity of agreements that restrict effective competition, ${ }^{8}$ damages payable to the injured persons, ${ }^{9}$ and in special circumstances under Slovenian law, an infringement of competition rules can also qualify as a criminal offence ${ }^{10}$ for which not only natural persons, but also legal entities can be responsible. ${ }^{11}$

In order to impose the above-mentioned sanctions there are two important issues that need to be addressed. The first issue is what constitutes a restriction of effective competition. This issue requires a complex analysis of competition rules in light of the objectives of competition law. ${ }^{12}$ Due to the complexity and broadness of the subject matter, it cannot be dealt with in this paper. Therefore, this paper is dedicated to the second important issue only - to the entities that are obliged to follow competition rules and are responsible for the infringement of these rules. Accordingly, two matters should be mentioned. Firstly, this paper deals with the notion of an undertaking, with special emphasis on the public entities such as states, local communities, public agencies and other institutions, and their qualification as addressees of competition rules. Secondly, it deals with this issue mainly under the Slovenian competition regulation, including the case law of the Slovenian Competition Protection Office (hereinafter referred to as Office) and the courts. However, it has to be stressed that for the reasons mentioned below, there is no major difference in the interpretation of the undertaking under the Slovenian and EU competition law. Therefore, the solutions 
adopted by the EU Commission and EU Court (hereinafter referred to as Court) can also be acceptable for Slovenian Office and courts.

As in other EU Member States, there are two competition law systems in force in Slovenia, i.e., EU competition law and Slovenian national competition law. The applicability of EU competition law depends on whether the case at issue is related to either antitrust law (e.g., an agreement restricting competition, abuse of a dominant position) or control of concentrations between undertakings (e.g., mergers). Therefore, EU law is applicable only there where an agreement or abuse might appreciably affect trade between Member States, ${ }^{13}$ and where a concentration has an EU dimension - a criterion based on the turnover of undertakings concerned in a concentration. ${ }^{14}$ Otherwise, there are no considerable differences between Slovenian and EU competition laws. With a few minor differences, Slovenian legislator modelled the SCA on relevant competition provisions of the Treaty Establishing the European Community ${ }^{15}$ (now the TFEU after the Treaty of Lisbon ${ }^{16}$ has entered into force), EU Regulations, and the case law of the Court. In addition, the practice of the Office and national courts reveals that also the rules established in cases before the Court are used as references in competition cases that are otherwise dealt with national law. Therefore, this paper also refers to the EU case law where it is relevant and necessary to explain the subject matter of this paper, especially where no case law exists in Slovenia.

The first part of this paper briefly explains the purpose of competition law and the regulation in this field of law in the Republic of Slovenia. It also briefly describes various forms of competition restrictions that are identical to those under EU competition law. The second part deals with the concept of an undertaking and an association of undertakings in competition law as it has evolved over the years, including the 'single economic entity' doctrine and its importance in understanding the concept of an undertaking in competition law. The last part is dedicated to public entities and their possible classification as undertakings, with special emphasis on the case law of the Office, Slovenian national courts, and the EU Court where necessary.

\section{Competition Law and the SCA}

Competition law exists to protect competition in a free market economy, i.e., in an economic system in which allocation of resources is determined exclusively by supply and demand in free markets and not by government regulation. The fundamental element of this system is competition between entities, which leads to low prices, innovations, better quality, and a wide selection of goods and services. The main purpose of competition law is thus to prohibit and to punish anticompetitive conduct. It is defined as any conduct that creates outcomes opposite to those provided by effective competition. 
The part of the Slovenian competition law that deals with the prevention of restriction of effective competition is regulated by the SCA. ${ }^{17}$ According to this Act, the conduct of undertakings aimed at eliminating or preventing competition between players in the market is prohibited (e.g., when companies agree to fix prices or to set production quotas, etc.). The SCA distinguishes between anticompetitive conduct of undertakings and anti-competitive conduct of public entities, also known as state restrictions on competition. The anti-competitive conduct of undertakings includes: agreements or decisions made by an association of undertakings, concerted practices between undertakings that have as their object or effect the prevention, restriction, or distortion of competition (Article 6 of the SCA), ${ }^{18}$ abuse of a dominant position (Article 9 of the SCA), ${ }^{19}$ and concentrations between undertakings that significantly impede effective competition, particularly by creating or strengthening a dominant position (Article 11 of the SCA) ${ }^{20}$ The aim of the prohibition under Article 6 of the SCA is to provide independence for each undertaking to make decisions relevant to the market. Co-operation between undertakings on prices, production quotas, market share, etc. is thus strictly prohibited. Article 9 of the SCA refers to unilateral conduct of dominant undertakings. These are undertakings that possess significant market power, allowing them to act to a significant degree independently of their competitors, clients, or consumers. Examples of abuse of a dominant position are discriminatory pricing, predatory pricing, tying, refusal to deal, etc. Regarding concentrations between undertakings, only those that significantly impede effective competition are prohibited. ${ }^{21}$ However, it should be mentioned that all the concentrations that meet the economic criteria laid down in Article 42 of the SCA should be notified to the Office or to the EU Commission (in the event that they are qualified as concentrations with EU dimensions) regardless of whether or not they would significantly impede effective competition.

On the other hand, state restrictions of competition are as a rule prohibited, except in special circumstances provided by law. Thus, the Government of the Republic of Slovenia, state bodies, local community bodies, and individuals exercising public authorisations may not restrict the free operation of undertakings in the market (Article 64 of the SCA). An example of such restriction would be if the state directly or indirectly created discrimination among undertakings with respect to their registered offices, or the prohibition of trade in goods and services outside the local community area (Article 66 of the SCA). State restrictions of competition are the matters that should not be regulated by the SCA. The reason is that besides eliminating, they have nothing in common with restrictions made by undertakings. Anyway, the Slovenian legislator did not decide to regulate them with a special act other than the SCA.

Since this paper concentrates on anti-competitive conducts of undertakings, the term 'competition rules' is used to refer to those conducts only. Nevertheless, it should be emphasised that the notion of an undertaking as understood in competition law is broad enough to encompass public authorities and other public 
entities that can also be punished for coordinating their conduct, or for abusing a dominant position ${ }^{22}$ because they too can act as undertakings. Therefore, a public entity is not prevented from being outside the prohibition contained in Articles 6, 9 , and 11 of the SCA. The case law shows that many public entities have been under investigation by the Office or the EU Commission for infringing competition rules, and that they have been even condemned for restricting competition in the market.

\section{The Notion of an 'Undertaking' and an Association of Undertakings}

\subsection{Undertakings Engaged in Economic Activities}

Apart from the section dealing with state restrictions on competition, the SCA applies only to undertakings and associations of undertakings (Articles 4(1) and 3 of the SCA). The notion of an undertaking should be interpreted in the same way for the purpose of eliminating competition by agreement, for abuse of a dominant position, and for concentrations between undertakings. ${ }^{23}$ The same interpretation already results from the general provisions of the SCA in Article 3. It defines the term 'undertaking' by virtue of provisions referring to agreements, abuse of a dominant position, and control of concentrations without making any distinction between these different forms of prevention or elimination of competition. ${ }^{24}$ In addition, the same interpretation is also substantiated by the fact that these different lines of conduct are somehow connected. Control of concentration has a preventive role in assessing abuse of a dominant position because it prevents the creation of a dominant position and its potential abuse in the future. The rules that prevent restrictions of competition by agreement are not suitable to regulate concentrations because they refer only to the conduct between independent undertakings, while the purpose of concentrations leads to the loss of independence of those undertakings over which control is exercised. ${ }^{25}$ And finally, the connection between a restriction of competition by agreement and abuse of a dominant position results from the fact that only the unilateral conduct of an undertaking is subject to Article 9 of the SCA, while Article 6 of the SCA requires collusion between undertakings as a condition for applicability (see also Wils, 2000: 106).

The notion of an undertaking has a specific connotation in competition law, and it is not in accordance with the notion of an undertaking as understood in company law. According to the Slovenian Companies Act (OJ RS, No. 65/2009(ZGD-1UPB3) of 14 August 2009), an undertaking is just an organised bundle of personal and material resources needed to carry out commercial activities. Therefore, it is just an object, and not a subject of law (Ivanjko, 2009: 105). The position of an undertaking is quite different in company law where an undertaking is understood as a subject of law. As in EU competition law, the notion of an undertaking under the SCA rules requires a broad interpretation. According to Article 3(1)(1) of the SCA, an undertaking is an entity engaged in an economic activity regardless of the 
legal status of the entity or the way in which it is financed. ${ }^{26}$ Therefore, the SCA does not enumerate addressees of competition law rules by their legal status or form such as a company limited by shares, a limited liability company, an entrepreneur, etc. Instead, it uses a general denomination - performing an economic activity. Only the function of the activity carried out by the entity concerned is important and not the nature of the entity itself. This has two important implications. First, not only are companies the addressees of competition rules, but also individuals, professions, ${ }^{27}$ partnerships, sport clubs, and others. Second, there are certain fields that are excluded from the scope of competition rules. These are: a field of private use, a field of workers, and a field of carrying out public authority (Kling \& Thomas 2004, 505). This paper deals with the last exemption under which only entities engaged in economic activities must act according to the competition rules, whilst entities performing tasks in the public interest fall outside the scope of these rules (Jones \& Sufrin, 2008: 128).

Since the notion of an undertaking refers to an economic activity, the critical question is what constitutes such an activity. First of all, it should be pointed out that an economic activity is not a synonym for a profit-making activity, which is performed with the purpose of making a profit. It is also not necessary that a body be set up for an economic purpose. ${ }^{28}$ An economic activity is defined by the SCA as an activity performed for pay in the market (Article 3(1)(2) of the SCA) ${ }^{29}$ Therefore, there are two criteria for determining an economic activity: performing an activity in the market and performing an activity for pay. The first criterion indicates that market participants must make independent decisions about market parameters (such as price, production quota, etc.), while the second criterion excludes the activities that are performed without pay, or the activities where users do not pay for goods or services received, but instead, they make a contribution, or pay a fee, etc. According to this, the notion of an economic activity is broader than a profit-making activity because it also encompasses activities where payment is made only for covering expenses without any profit being made. Such a conclusion was confirmed by the Office in the case of the Slovenian Spas Association. ${ }^{30}$ It deals with the restriction of competition by agreement under Article 6 of the SCA (ex Article 5 of the SCA (1999)). An undertaking under investigation claimed that the Office was not competent to give any decision because the SCA was not applicable to the case concerned. The undertaking under the investigation was an entity engaged in natural health spa activities performed as public services. Consequently, the entity carried out no profit-making activity. The Office decided that, for the application of competition rules, it was not required that activities should be performed for the purpose of making a profit. Only performing an activity for pay is of importance. There is no doubt that natural spa activities are performed in the market and offered to customers for payment. The fact that the prices for medical treatment services were fixed by an agreement between the Slovenian Spas Association, the Health Insurance Institute of Slovenia, and the Ministry of Health was also irrelevant in this case. A similar outcome was reached in the case Festival Ljubljana/Cankarjev dom. ${ }^{31}$ In this case, 
the undertakings under investigation for infringement of Article 6 of the SCA (ex Article 5 of the SCA (1999)) were claimed to be non-profit public institutes in the field of culture, and thus outside the scope of competition rules. According to the decision of the Office, both entities were treated as undertakings because they performed their activities in the market and for pay. The payment represents the price of the tickets for a social event, the rent of premises, etc. Both entities also made independent decisions about market parameters. ${ }^{32}$ Therefore, the activity function is important. This means that the activities generally known as noneconomic can also be economic under the competition rules.

\subsection{Association of Undertakings}

Under the provisions of the SCA, an association of undertakings, not directly performing an economic activity, but affecting or might be affecting undertakings' activities in the market, is also subject to competition rules. An association consists of several undertakings in a particular industry, and it represents and protects the mutual interest of its members against other undertakings and public bodies. An association may provide a forum for competitors to meet, and to discuss the issues that are in their mutual interest. Thus, it can be a perfect vehicle through which undertakings can co-ordinate their actions (Jones \& Sufrin, 2008: 146). Examples of such associations, which were also under the investigation of the Office, are the Slovenian Spas Association, the Slovenian Chamber of Pharmacy, ${ }^{33}$ the Slovenian Tourist Agencies Association, ${ }^{34}$ the Association of Banks, ${ }^{35}$ etc.

The main purpose of including an association of undertakings among the addressees of competition rules is to ensure that undertakings do not evade competition rules by establishing an association that makes decisions for all its members. When determining an association of undertakings, it is not relevant whether the association has a legal personality, undertakings are permanently linked, membership is binding or voluntary, or regarding the founder of the association, etc. ${ }^{36}$ Although legal personality is not crucial to qualify associations as undertakings, it is relevant for the imposition of fines. Article 73 of the SCA provides that only natural and legal entities and entrepreneurs can be fined for breach of competition rules. Thus, an association with no legal personality, although it is an undertaking and found in breach of competition rules, cannot be fined under Slovenian regulations. ${ }^{37}$

\subsection{Single Economic Entity}

For the correct interpretation of the concept of 'undertaking' under the competition rules, one must also turn to the so-called 'single economic entity' doctrine. The companies belonging to the same group and having, e.g., the status of parent and subsidiary may have distinct legal personalities, but they are not necessarily independent in an economic sense. This means that a subsidiary has no 
freedom to determine its conduct in the market, ${ }^{38}$ and it must follow the instructions given by its parent company. Since subsidiaries lack autonomy, they form one entity together with their parent companies (Jones \& Sufrin, 2008: 141). Consequently, the agreements between parent and subsidiary companies are not prohibited because there is no co-operation between at least two undertakings as required by law. ${ }^{39}$ Thus, the notion of an 'undertaking' encompasses only undertakings that have economic independence in order to be subject to competition rules. ${ }^{40}$ One of the most obvious examples of such a single economic entity is there where one company owns a $100 \%$ share in another company. As for other cases, the important question is which factors can be taken into account to establish such a single economic entity. Articles 3(1)(3) and (4) of the SCA contain definitions of 'controlling' and 'controlled undertaking, ${ }^{41}$ The question is whether these rules are suitable to define a single economic entity. It should be emphasised that these rules are intended to estimate the aggregate turnover of the undertakings belonging to the same group of undertakings in order to determine whether or not the Office should be notified of a concentration under Article 43 of the SCA. This means that they indicate only formal control and not actual control $^{42}$ as regulated under Article 10 of the SCA, which is intended to establish whether certain transactions can be qualified as concentrations. ${ }^{43}$ Thus, in our opinion, the rules under Articles 3(1)(3) and (4) of the SCA cannot be relevant guidelines for the determination of a single economic entity. Therefore, it is more appropriate to apply the rules under Article 10 of the SCA in relation to the existence of concentrations between undertakings (see also Wils, 2000: 106; Whish, 2003: 88-89, and Faull \& Nikpay, 2008: 207 regarding EU competition law). Under these rules, a concentration between undertakings exists if an undertaking has the possibility of exercising decisive influence over another undertaking, i.e., to exercise influence on the strategic decisions of another undertaking (e.g., decisions relating to budget, business plan, larger investments, etc.). This means that any undertaking over which control can be exercised lacks decision-making autonomy, and this is exactly the purpose of the 'single economic entity' doctrine.

We can also draw such a conclusion from the Slovenian case law. In the Slovenian Bank case,${ }^{44}$ four banks were found in breach of competition rules because they agreed to a provision to charge for withdrawing money from cash machines. They all introduced a commission in the same amount on the same day. During the proceedings, the question arose as to whether two of them formed a single economic entity. The Office referred to the possibility of exercising decisive influence and indicated non-exhaustive criteria that could be useful in this regard, e.g., a majority share in the subsidiary, appointment of the management and supervisory board members, transfer of profits to the parent company, etc. 


\subsection{A Brief Introduction to the Public Entities in Republic of Slovenia}

Legal entities or artificial persons created by legal acts can be divided into private legal entities and public legal entities. This division is the result of a well-known distinction between private and public law. While the foundation of private law is the right of each individual to be the subject of legal relations and to shape them according to his or her will, public law is characterised by the exercise of official authority. The basic characteristic of a public legal entity is the foundation act in the form of a legal act or other official act. In addition to the nature of the foundation act, there are some other ancillary criteria that help define a public entity. These are exercise of official authority, obligatory membership in an entity, use of force, etc. (Trstenjak, 2003: 100-102; Pirnat, 1999: 912; Bohinc, 2005: 68). While the classification of private entities as undertakings is not problematic, the same cannot be said for public entities such as states, local communities, public funds, public agencies, and public institutes.

The purpose of this paper is not to discuss thoroughly which entities in Slovenia should be qualified as public legal entities, considering that many authors in Slovenia have already taken much effort to deal with this issue. In addition, this qualification is irrelevant to the issue of addressees of competition rules where the only relevant criterion (as we have seen) is to perform an economic activity. The prevailing opinion is that public entities in Slovenia are especially the State, local communities, public agencies, chambers (e.g., Chamber of Commerce and Industry of Slovenia, Notary Chamber of Slovenia, Slovenian Bar Association), public institutes, public funds, etc. Authors also quote public undertakings ${ }^{45}$ (see Pirnat, 1999: 919; Kranjc, 2007: 77), i.e., those undertakings over which public authorities may directly or indirectly exercise a dominant influence by virtue of their ownership, their financial participation therein, or the rules which govern it (see Zabel, 2000: 26) ${ }^{46}$ as public entities.

\subsection{Public Entities as Addressees of Competition Rules}

It is well established that public entities can be undertakings under the competition rules insofar as they perform an economic activity. In the case of Pavel Pavlov and Others $v$ Stichting Pensioenfonds Medische Specialisten, ${ }^{47}$ the Court held that the fact that a professional organisation is governed by a public-law statute does not preclude the application of competition rules. Although there is no provision that would explicitly include public entities and public undertakings as addressees of the competition rules in the new SCA (2008), this does not and cannot mean that they are completely outside the scope of competition rules. These rules are not applicable to them only when they exercise official authority, i.e., when they perform an activity of a typical public nature or when their activity is dedicated to performing public interest work that is part of the principal state function (see 
Grilc, 2009: 60). ${ }^{48}$ Though this delimitation seems to be simple, in reality, it is often far from that (see also Loozen, 2009: 34). There is also another difficulty concerning those entities that not only exercise public authority, but also perform an economic activity. The question is whether we should treat them as undertakings. The answer, of course, is of crucial importance for the reasons mentioned above. It is well established that the notion of an undertaking requires assessing the entity as an undertaking in each individual case. This is due to the concept of the relative notion of an undertaking (see Säcker, Herrmann, 2007: 458). Therefore, it is quite possible that an entity is qualified as an undertaking under certain circumstances, but not in others (Faull \& Nikpay, 2008: 189). Thus, every single activity of an entity should be assessed in each individual case.

The old SCA (1999) contained a provision regarding public entities and public undertakings in Article 2(4) that provided:

"This Act applies to public undertakings and other public entities performing an economic activity, unless otherwise provided by the act."

According to this provision, there were two possible ways to exclude the application of the SCA. First, if an activity was not economic, and second, if an activity was found to be economic, but it could take advantage of the derogation from competition rules provided by other legal acts. ${ }^{49}$ In this respect, before the Office, the question arose of the interpretation of the last part of the provision that refers to rectifying this issue in other acts. In the case of Festival Ljubljana/Cankarjev dom, ${ }^{50}$ the Office held that undertakings co-ordinated their conduct and thus infringed competition rules. They informed each other about event performances, prevented other organisers from organising events, agreed on the competition clause, accepted obligations to use the facilities, etc. The question was whether Festival Ljubljana and Cankarjev dom could be classified as undertakings and subject to competition rules. Both undertakings are public institutes and consequently public entities. Festival Ljubljana claimed that Article 4(2) of the SCA (1999) should apply subsidiarily to public entities when stating that the SCA was only applicable if not otherwise provided by other acts. The Office held that the provision concerned does not mean that it applies subsidiarily to public undertakings and public entities, but that it may be excluded by virtue of another legal act or by using different methods of rectifying certain issues. Thus, the conduct of the undertakings concerned would not be dealt with under the SCA only in the case of a special legal act that would exclude the applicability of the SCA or would provide different regulations for certain types of entities. For this purpose, the Office closely examined other possible legal acts and ascertained that none of them would exclude the application of the SCA in the given case.

Although Article 2(4) of the SCA (1999) is no longer in force, the idea behind this provision can still be very much alive. Public entities and undertakings can be subject to other rules that exclude the application of competition rules (i.e., SCA). 
This would presumably be in the cases where their activity is of general interest or where certain conduct of undertakings is required by legislation. As already mentioned, the SCA (2008) has no such provision, not even similar to the provision of Article 2(4) of the SCA (1999). The question is whether the inclusion of such a provision in the SCA is necessary. The preparatory documents for the SCA bill are silent on this issue and do not explain any reasons for the abandonment of this provision, but the reason for that may lie in the fact that such entities are already covered by the definition of 'undertaking' under Article 3 of the SCA. The term 'undertaking' referred to in Article 3 of the SCA is clear enough and does not need any further explanation as to the inclusion of public entities and public undertakings as addressees of competition rules. Nevertheless, such an inclusion (especially as regards the last part of the former Article 2(4) of the SCA (1999) that points to other legislative acts that derogate from the application of competition rules) would be appropriate for the sake of legal certainty.

In addition to the already mentioned case of Festival Ljubljana/Cankarjev dom, where public institutes were treated as undertakings because they were receiving financing through selling goods and services in the market, the Office treated several other public entities as undertakings. In the case of ZZV Maribor/DDD Koper, ${ }^{51} \mathrm{ZZV}$ Maribor was accused of collusive tendering and thus restricting competition by agreement. ZZV Maribor is the Maribor Public Health Institute established to perform social and medical, epidemiological, and health-ecological activities in certain regions of Slovenian local communities. It acquires financial assets not only from public funds, but also from selling services in the market. The Office found it to be an undertaking. In the JKP Log case, ${ }^{52}$ an entity was accused of allegedly abusing its dominant position by discriminating against the Primožič Company because it refused to give access to performing certain funeral activities that were otherwise allowed to be performed by other companies. The JKP Log Company was established to perform funeral activities as a public service. Therefore, it was treated as an undertaking under the competition rules. It was established by legal acts, and its function was to perform several community activities. The same conclusion was reached in the case of Pogrebno podjetje Maribor $^{53}$ where the undertaking performing funeral activities was accused of allegedly abusing its dominant position in the relevant market by imposing unfair trading conditions, applying dissimilar conditions to equivalent transactions with other trading parties, and tying. Pogrebno podjetje Maribor was granted public power by the local community to perform public commercial service for two cemeteries in the Maribor region. It was also treated as an undertaking.

The Court also handled many other such cases. In the case of Klaus Höfner and Fritz Elser v Macrotron, ${ }^{54}$ a German Federal Employment Agency was found to be an undertaking. Its employment procurement activities were economic in nature, and they were not necessarily provided by the State. Thus, the activity performed did not form part of the essential functions of the State (Faull \& 
Nikpay: 2008, 192-193). The decision of the Court was different in the Corinne Bodson case ${ }^{55}$ where competition rules did not apply to the agreements concluded between communities acting in their capacity as public authorities and undertakings entrusted to perform funeral services. There were similar rulings in the cases of SAT Fluggesellschaft v Eurocontrol ${ }^{56}$ and Diego Cali \& Figli Srlvi Servizi ecologici porto di Genova SpA (SEPG).$^{57}$ In Eurocontrol, an air traffic control organisation involved in maintenance and improvement of air navigation safety was not ruled as an undertaking, even though it collected route charges. The Court held that Eurocontrol acted on behalf of the State without having any influence over the amount charged. In Diego Cali case, the activities of the company, which exercised an exclusive right to provide services relating to the protection of the environment, were not economic, although the company charged a fee set by the Genoa Port Authority for providing these services. The Court held that these services were part of an essential state function relating to the protection of the environment.

We can deduce from the case law that despite the fact that performing an activity for pay is a crucial condition for the determination of an undertaking under the SCA, it is not necessarily always conclusive or, if we put it more precisely, sometimes the lines are blurred. This is the case where organisations exercise the powers that can be seen as part of the prerogative of the State, for example, where an organisation is under State control and fees are set by the State. It is also true that the fact that a certain activity is performed in the public interest or an entity performs public services is not necessarily enough for competition rules not to be applied (Faull \& Nikpay, 2008: 193). In the case of Firma Ambulanz Glöckner v Landkreis Südwestpfalz, ${ }^{58}$ a medical assistance organisation was found to be an undertaking, even though it was entrusted with these activities by law. The Court held that users paid for services, and that the latter did not have to be carried out by that organisation or any other public organisation.

In EU case law, social security and health insurance funds posed particular problems regarding the notion of undertakings in competition law. In these cases, the Court referred to the principle of solidarity in the performance of funds, and it did not so much rely on the question of whether the services in question can be provided in the market (Jones \& Sufrin, 2008: 617). ${ }^{59}$ This principle has become a general tool to distinguish between economic and non-economic activities, and, consequently, between undertakings and entities that cannot be qualified as such. If activities are performed based on solidarity, the organisation is considered to be an undertaking, and vice versa. The principle of solidarity as a means of redistribution of income between those who are better off and those who are deprived of the necessary social coverage manifests itself in individual contributions that are not proportionate to the individual risk insured, and the amount of benefits paid is not linked to the individual's earnings. For this purpose, compulsory membership is also important to uphold the principle of solidarity (Boeger, 2007: 327; see also Krajewski \& Farley, 2004: 847). 
As can be seen from the above-mentioned Slovenian case law referring to the issue of public entities as undertakings, the Office and courts did not make any proper analysis of whether a public entity was exercising public authority or not. Perhaps in these cases, the question was fairly obvious, and therefore it required no in-depth analysis. Regarding complex cases in the future, one could refer to EU case law and use the guidelines of the Court, which would be much helpful in deciding cases where it is not so clear at first sight whether or not an entity exercises public authority. It is a well-established practice in Slovenia that the Office and the Slovenian national courts apply the rules established in the cases before the Court as references when deciding competition cases.

\section{$5 \quad$ Conclusion}

Public entities should follow two different sets of rules in the SCA. The first set includes the rules referring to state restrictions on competition in Articles 64-72 of the SCA under which public entities are prohibited from restricting undertakings' free entry into the market. The second set includes the rules that prohibit anti-competitive conduct of undertakings. Although public entities are established by law, and thereby performing public functions, they are not absolutely safe from competition rules that otherwise apply to business / commercial entities.

Regarding the anti-competitive conduct of the undertakings dealt with in this paper, we can draw the following conclusions. Firstly, public entities can be undertakings as they are understood in the language of competition law when they perform an activity for pay in the market. An example of such an activity would be a local community that sells certain appliances in the market or rents its own facilities. Secondly, public entities are not undertakings only when they exercise public authority. And thirdly, in the case of social security and health insurance funds, the solidarity principle in the performance of such funds is of importance in deciding whether or not entities can qualify as undertakings for the purposes of competition rules.

\section{Notes}

1 OJ C 115 of 9 May 2008.

${ }^{2}$ OJ L 1, 04.01.2003, p. 1-25.

${ }^{3}$ OJ L 24, 29.01.2004, 1-22.

${ }^{4}$ See Article 23(2) of Regulation 1/2003 and Article 14(2) of Regulation 139/2004.

5 OJ RS, No 36/2008 of 11 April 2008 (ZPOmK-1) and No 40/2009 of 29 May 2009 (ZPOmK-1A).

6 OJ RS, No 56/1999 of 13 July 1999 (ZPOmK).

${ }^{7}$ Prior to the enactment of the SCA in 2008, fines were levied in a range from 125,000 to 375,000 euros. But it should be stressed that the Administrative Offences Authority had the power to impose a maximum fine of only 125,000 euros in accordance with the Minor 
Offences Act (OJ RS, No 7/2003 of 23 January 2003; ZP-1). It provides that in summary procedures (as in the case concerned), the authority can impose only the lowest fines prescribed by the Act, unless otherwise provided by law. SCA 1999 did not use that possibility and therefore did not provide otherwise.

${ }^{8}$ See Article 6(1) of the SCA, and Article 101(2).

9 Article 62(1) of the SCA. Damages can also be claimed for the infringement of EU competition rules.

${ }^{10}$ See Article 225 of the Penal Code of the Republic of Slovenia (OJ RS, No 55/2008 of 4 June 2008; KZ-1).

${ }^{11}$ See the Criminal Liability of Legal Entities Act (OJ RS, No 98/2004 of 9 September 2004; ZOPOKD-UPB1, and No 65/2008 of 30 June 2008; ZOPOKD-B).

12 See Nazzini, 2006: 529-530; Odudu, 2002: 100-105; Marquis, 2007: 38; Cerulli Irelli, 2009: 287-306; Rousseva, 2005: 587, and others.

${ }^{13}$ See Commission Notice - Guidelines on the effect on trade concept contained in Articles 81 and 82 of the Treaty (OJ C 101 of 27 April 2004, p. 81-96.

${ }_{14}$ See Article 1 and 5 Regulation 139/2004. See also Commission Consolidated Jurisdictional Notice under Council Regulation (EC) No 139/2004 on the control of concentrations between undertakings (OJ C 95, 16 April 2008).

${ }^{15}$ OJ C 325 of 24 December 2002 (consolidated text).

${ }^{16}$ The Treaty of Lisbon Amending the Treaty on European Union and the Treaty Establishing the European Community, signed in Lisbon, 13 December 2007 (OJ C 306 of 17 December 2007).

${ }^{17}$ The second part of the competition law is the lae against unfair competition that is regulated by the Protection of Competition Act (OJ RS, No 18/1993 of 9 April 1993). Its goal is to establish and maintain fair play among market participants. Accordingly, any unfair advertisement, use of another company's signage, etc., are prohibited.

${ }^{18}$ Comparable provision is Article 101 TFEU.

${ }^{19}$ Comparable provision is Article 102 TFEU.

${ }^{20}$ Comparable provision is Article 2 of Regulation 139/2004.

${ }^{21}$ So far, the Office has prohibited only one concentration between undertakings in the case of Delo/Večer (case 306-195/2008 of 23 September 2009).

${ }^{22}$ The same can be said for public undertakings.

${ }^{23}$ It should be mentioned that provisions regarding the control of concentrations between undertakings also refer to individuals (SCA, Article 10).

${ }^{24}$ The position is the same under EU competition law.

25 Article 10(2) of the SCA.

${ }^{26}$ It can be seen that this definition of 'undertaking' employs EU case law in Höffner and Elsner v Macroton, Case C-41/90, ECR 1991, p. I-1979.

${ }_{27}$ Pavel Pavlov and others v Stichting Pensioenfonds Medische Specialisten, Case C-180/98 to C-184/98, ECR 2000, p. I-6451.

${ }^{28}$ Italy v Sacchi, Case 155/73, ECR 1974, p. 409.

${ }^{29}$ Under the EU competition rules, an entity can be considered an undertaking if it offers goods and services in a given market. The EU Court held in Fenin v Commission (case C205/03P, ECR 2006, p. I-6295) that purchasing medical goods from third parties is not an economic activity if these goods are subsequently used to provide health services on a noneconomic basis. See Krajewski \& Farley, 2007: 111 and seq., Ross, 2007: 1068, and Kling \& Thomas, 2007: 57.

${ }^{30}$ Case 306-83/2005 of 19 January 2006.

${ }^{31}$ Case 3072-4/00 of 19 June 2001. 
32 This conclusion can also be deduced from the EU case law (case C-244/94, Fédération Française des Sociétés d'Assurances and Others v Ministère de l'Agriculture et de la Pêche, ECR 1995, p. I-4013).

33 Case 3072-11/2003 of 1 February 2005.

${ }^{34}$ Case 306-89/2005 of 20 February 2006.

${ }^{35}$ Case 306-62/2005 of 15 November 2006.

${ }^{36}$ Case 306-62/2005 of 15 November 2006.

${ }^{37}$ See case (Administrative Court) U 537/2004 of 24 January 2006.

38 This doctrine also applies to relations between principal and commercial agent. See Case 306-21/2005 of 1 February 2006.

39 Article 6(1) provides: 'Agreements between undertakings, decisions of business associations and concerted practices of undertakings whose object or effect is to prevent, restrict or distort competition in the Republic of Slovenia shall be prohibited and shall be null and void'.

${ }^{40}$ See also Article 10 of the SCA under which transactions between undertakings are not treated as concentrations in the case of the so-called internal restructuring (e.g., two whollyowned subsidiaries merge).

${ }^{41}$ Article 3(3) of the SCA states: "A controlling undertaking shall mean an undertaking that, directly or indirectly:

- holds a majority of interests in capital or business shares in another undertaking;

- holds a majority of voting rights in another undertaking;

- has the right to appoint or remove a majority of the members of the management or supervisory board of another undertaking; or

- has the right to manage the affairs of another undertaking on the basis of business contract or other legal arrangement."

42 Under formal control, more than half of the capital in another undertaking is enough to establish a group of undertakings, while this is not necessarily true for the establishment of actual control that is linked to voting rights.

43 See also Broberg, 1998: 63-65 as regards the control of concentrations under the EU competition rules.

${ }^{44}$ Case 306-14/2006 of 26 February 2007.

${ }^{45}$ It should be emphasised that public undertakings as understood in EU law are not always public entities. Under EU law, the notion of public undertakings encompasses all the undertakings that are directly or indirectly controlled by the state regardless of whether they are private or public entities (Kranjc, 2007: 77).

${ }^{46}$ See more about the Slovenian regulation of public undertakings at Brezovnik, 2009: 185 and seq.

${ }^{47}$ Case C-180/98 to C-184/98, ECR 2000, p. I-6451.

${ }^{48}$ The same is true under EU competition rules (see Säcker \& Herrmann, 2007: 455).

${ }^{49}$ Such a derogation is contained in Article 106(2) TFEU under which public undertakings, entrusted with services of general economic interest if they are otherwise obstructed in the performance of their tasks, are not bound to follow competition rules. This means that entities can be found to be undertakings, but they are nevertheless excluded from the scope of competition rules according to Article 106(2) TFEU. See more at Brezovnik, 2009: 180; Faull \& Nikpay, 2008: 626 and seq.; Ross, 2009: 130-138, Gundel, 2007: 1308 and seq.). According to our knowledge, there is no such a general derogation provision in Slovenian regulation.

${ }^{50}$ Case $3072-4 / 00$ of 19 June 2001.

51 Case 306-51/2005 of 27 October 2006 (from decision 306-1000/2006; 4/2006 of 9 November 2006).

${ }^{52}$ Case 3073-11/2003 of 13 July 2007. See also case (Administrative Court) U 259/2004-17 of 8 March 2005 and the case (Slovenian Supreme Court) [...] of 21 March 2006. 
${ }^{53}$ Case 3073-4/2001 of 18 August 2003. See also case (Administrative Court) U 360/2003-26 of 21 January 2006.

${ }^{54}$ Case C-41/90, ECR 1991, pp. II-159.

55 Case 30/87, Corinne Bodson s SA Pompes Funèbres des Régions Libérées, ECR 1988, p. 2479.

${ }^{56}$ Case C-364/92, SAT Fluggesellschaft v Eurocontrol, ECR 1994, p. I-43.

${ }^{57}$ Case 343/95, ECR 1997, p. I-1547.

${ }^{58}$ Case C-475/99, ECR 2001, p. I-8089.

59 See cases C-159/91 and 160/91, Christian Poucet v Assurance Générales de France and Caisse Matuelle Régionale du Languedoc-Roussillon, ECR 1993, p. I-637, Federación Nacional de Empresas de Instrumentación Científica, Médica, Técnica y Dental (FENIN) v Commission, Case C-205/03P, ECR 2006, p. I-6295, Fédération Française des Sociétés d'Assurances in drugi v Ministère de l'Agriculture et de la Pêche, Case C-244/94, ECR 1995, p. I-4013, Albany International BV v Stichting Bedriifspensioenfonds Textielindustrie, C-67/96, ECR 1999, p. I-5751, C-264/01, AOK Bundesverband and Others v Ichthyol-Gesellschaft Cordes, Hermani \& Co. and Other, ECR 2004, p. I-2493.

\section{References}

Bohinc, R. (2005) Osebe javnega prava (javni zavodi, javna podjetja, javne agencije, javni skladi (Ljubljana: GV Založba).

Boeger, N. (2007) Solidarity and EC competition law, European Law Review, 32(3), pp. 319-340.

Brezovnik, B. (2009) Topical Issues on the Legal Regulation of the Public Enterprise in Slovenia, Lex Localis - Journal of Local Self-Government, 7(2), pp. 177-195.

Broberg, M. P. (1998) The European Commission's jurisdiction to scrutinise mergers (The Hague/London/Boston: Kluwer Law International)

Cerulli Irelli, V. (2009) Article 81(1) EC: some remarks on the notion of restriction of competition, European Business Law Review, 20(2), pp. 287-306.

Faull, J. \& Nikpay, A. (2007) The EC law of competition (New York: Oxford University Press).

Grilc, P. (ed.) (2009) Zakon o preprečevanju omejevanja konkurence (ZPOmK-1) s komentarjem, (Ljubljana: GV Založba).

Gundel, J., Hirsch, G., Montag, F. \& Säcker, F. J. (2007) Münchener Kommentar zum Europäichen und Deutschen Wettbewerbsrecht (Kartellrecht) - Kartellrecht Missbrauch- und Fusionskontrolle, Europäisches Wettbewerbsrecht (München: Verlag C.H.Beck München).

Hirsch, G., Montag, F. \& Säcker, F. J. (2007) Münchener Kommentar zum Europä̈chen und Deutschen Wettbewerbsrecht (Kartellrecht) - Kartellrecht Missbrauch- und Fusionskontrolle, Europäisches Wettbewerbsrecht (München: Verlag C.H.Beck München).

Ivanjko, Š., Kocbek, M. \& Prelič, S. (2009) Korporacijsko pravo - Pravni položaj gospodarskih subjektov (Ljubljana: GV Založba \& Pravna fakulteta Univerze v Mariboru).

Jones, A. \& Sufrin, B. (2008) EC competition law - text, cases, and materials (New York: Oxford University Press).

Kling, M. \& Thomas, S. (2007) Kartellrecht (München: Verlag Franz Vahlen).

Kling, M. \& Thomas, S. (2004) Grundkurs Wettbewerbs- und Kartellrecht (München: Verlag C. H. Beck).

Krajewski, M. \& Farley, M. (2004) Limited competition in national health systems and the application of competition law: the AOK Bundesverband case, European Law Review, 29(6), pp. 842-851.

Krajewski, M. \& Farley, M. (2007) Non-economic activities in upstream and downstream markets, and the scope of competition law after FENIN, European Law Review, 32(1), pp. $111-124$. 
Kranjc, V. (2007) Zakon o javnem naročanju, Zakon o javnem naročanju na vodnem, energetskem, transportnem področju in področju poštnih storitev, Zakon o reviæiji postopkov javnega naročanja s komentarjem (Ljubljana: GV Založba).

Loozen, D. (2006) Professional ethics and restraints of competition, European Law Review, 31(1), pp. 28-47.

Marquis, M. (2007) O2 (Germany) v Commission and the exotic mysteries of Article 81(1) EC, European Law Review, 32(1), pp 29-47.

Nazzini, R. (2006) Article 81 EC between time present and time past: a normative critique of "restriction of competition" in EU law, Common Market Law Review, 43(2), pp. 497-536.

Odudu, O. (2002) A new economic approach to Article 81 (1), European Law Review, 27(1), pp. $60-75$.

Pirnat, R. (1999) Pravne osebe javnega prava: sistem ali kaos, Podjetje in delo, 25(6-7), pp. 910922.

Ross, M. (2007) Promoting solidarity: from public services to a European model of competition?, Common Market Law Review, 44(4), pp. 1057-1080.

Ross, M. (2009) A healthy approach to services of general economic interest? The BUPA judgement of the Court of First Instance, European Law Review, 34(1), pp. 127-140.

Rousseva, E. (2005) Modernizing by eradicating: how the Commission's new approach to Article 81 EC dispenses with the need to apply Article 82 EC to vertical restraints, Common Market Law Review, 42(3), pp. 587-638.

Trstenjak, V. (2003) Pravne osebe (Ljubljana: GV Založba).

Whish, R. (2003) Competition law (London: LexisNexis).

Wils, P.J. (2000) The undertaking as subject of E.C. competition law and the imputation of infringements to natural or legal persons, European Law Review, 25(2), pp. 99-116.

Zabel, B., Grilc, P., Galič, A. \& Juhart, M. (2000) Zakon o preprečevanju omejevanja konkurence ( $\mathrm{PPOmK}$ ) s komentarjem (Ljubljana: Gospodarski vestnik). 